\title{
Digital currencies: Challenges between the United States, the European Union and Asia Pacific
}

\author{
Monedas digitales: desafíos entre Estados Unidos, la Unión Europea \\ y Asia Pacífico
}

\author{
Rosa María Ricoy-Casas \\ University of Vigo \\ rricoy@uvigo.es
}

Summary: I. Introduction. The FinTech.-II. The development of cryptocurrencies.-III. The race for a digital currency and its challenges.-IV. Other conclusions.

\begin{abstract}
In June 2019, Facebook announced its own cryptocurrency "Libra" to be used through WhatsApp and Messenger, in order for its value to remain stable thanks to the support from banks and electronic commerce companies, linking to different currencies and the support of important companies. EU antitrust regulators investigated it as a "threat to monetary sovereignty". China is already testing its own DCEP cryptocurrency tied to state banks and major companies, with notable advantages. It will probably displace cash and be used even for world trade, which can make it an alternative to the traditional international payment system, compared to the current one led by the United States with the USD. The Belt and Road Initiative (BRI) offers "the area and the route" to extend the Yen as a global digital currency. These new developments, and their rapid and high competitiveness produced as the "art of bian lian", have generated intense concerns in the international financial system. Will the EU, Japan or the US be able to counter the virtual yuan so quickly?
\end{abstract}

Keywords: digital currencies, cryptocurrencies, monetary system, governance.

Resumen: En junio de 2019 Facebook anunció su propia criptomoneda "Libra” para usarse a través de WhatsApp y Messenger, con la finalidad de que su valor permaneciese estable gracias al apoyo de entidades bancarias y empresas de comercio electrónico, vinculándose a diferentes divisas y el respaldo de importantes empresas. Los reguladores antimonopolio de la UE lo investigaron como "amenaza a la soberanía monetaria”. China ya se encuentra probando su propia criptomoneda DCEP vinculada a bancos estatales e importantes empresas, con notables ventajas. Probablemente desplazará el dinero en efectivo y se utilizará incluso para el comercio mundial, lo que puede convertirla en una 
alternativa al sistema de pagos tradicional internacional, frente al actual liderado por Estados Unidos con el USD. La Iniciativa (BRI) ofrece "la franja y la ruta" para extender el Yen como una moneda digital global. Estos nuevos desarrollos, y su rápida y alta competitividad producida como el "arte de bian lian", han generado intensas preocupaciones en el sistema financiero internacional. ¿Podrán la UE, Japón o EEUU contrarrestar con tanta rapidez el yuan virtual?

Palabras clave: monedas digitales, criptomonedas, sistema monetario, gobernanza. 


\section{Introduction. The FinTech}

In 2015, China announced a plan, published on May 8, 2015, the strategy to become a technological world power $(5 \mathrm{G}$, AI, robotics, aeronautics, cryptocurrencies, etc.), imposing its own norms and standards, in one decade (2015-2025) ${ }^{1}$. China is also the dragon of FinTech (Financial Technologies) in the global arena, within the aforementioned strategy, understood as companies that combine finance with technology to provide new financial services based fundamentally on the innovations provided by technology in this area, for example, Alipay (Ant Financial-Alibaba Group) and WeChat (Tencent), one-stop shops that allow half a billion Chinese to access an incredible variety of goods and services ${ }^{2}$ : payments, loans, investments, credit evaluation, taxi rides, travel reservations, social networks, etc. The value of e-money transactions in China, such as with WeChat Pay and Alipay, exceed those of Visa and Mastercard combined ${ }^{3}$.

As an author explains in MIT Technology Review ${ }^{4}$, so much is sold and products so varied through these applications, that Alibaba and Tencent know the economic situation of many small companies in China. As a result, they can give loans to companies that banks would consider too risky $^{5}$. The application of artificial intelligence to credit scoring makes it possible for individuals and small businesses with no credit history to access it. For this, these analyses consider non-financial variables, such as mobile phone use or behavior on social networks (online reputation) ${ }^{6}$. In

${ }^{1}$ Gómez Pérez-Cuadrado, E., "Plan Made in China 2025”, ICEX España Exportación e Inversiones (2016): https://www.icex.es/icex/es/navegacion-principal/todos-nuestros-servicios/informacion-de-mercados/paises/navegacion-principal/el-mercado/estudios-informes/ DOC2016671546.html?idPais $=\mathrm{CN}$

${ }^{2}$ López-Ibor, R.A., "Un análisis de la economía de plataformas y su regulación", Papeles Fundación Faes, n. ${ }^{\circ} 210$ (2018): https://fundacionfaes.org/file_upload/news/ pdfs/20180320123324.pdf; Brunnermeier, M. K., Harold, J. y Landau, J-P., "The Digitalization of Money", NBER Working Paper Series, n. ${ }^{\circ}$ w26300 (2019): https://www.nber.org/ system/files/working_papers/w26300/w26300.pdf

3 Mancini Griffoli, T. y Adrian, T., "The rise of digital money", Fintech Notes: International Monetary Fund (2019): https://www.imf.org/en/Publications/fintech-notes/ Issues/2019/07/12/The-Rise-of-Digital-Money-47097

${ }^{4}$ Chorzempa, M., "Por qué las 'fintech' triunfan en China pero no en el resto del mundo", MIT Technology Review (2019): https://www.technologyreview.es/s/10833/por-quelas-fintech-triunfan-en-china-pero-no-en-el-resto-del-mundo

${ }^{5}$ Gorjón, S., "El crecimiento de la industria fintech en China: un caso singular", Boletín económico del Banco de España (artículos analíticos) (2018): https://www.bde.es/bde/es/ secciones/informes/boletines/Boletin_economic/index2018.html

${ }^{6}$ Barruetabeña, E., "La influencia de las nuevas tecnologías en la inclusión financiera", Boletín económico del Banco de España (artículos analíticos) (2020): https://www.bde.es/ bde/es/secciones/informes/boletines/Boletin_economic/ 
more specific cases, such as loans for agricultural activities for small producers, data obtained by satellite are being used for credit scoring, which also reduces operational and logistical costs ${ }^{7}$.

Thus, they offer services not covered or poorly provided for by banking entities (they had structural deficiencies in their financial system), in an area where the use of credit cards was scarce. It also benefited from the Chinese government giving its tech giants far more freedom to innovate than US regulators would allow (the Chinese online payments market lacked regulation for years, and its privacy regulations are laughable). In the United States this would be unthinkable. For example, PayPal had to go State by State to request a licence to process payments. The North American country has also long maintained a separation between banking and non-financial companies. If Google wanted to have a bank, US regulators would force it to abandon its search and advertising businesses ${ }^{8}$.

Perhaps we can highlight other factors that have led to this success: electronic money transfers are carried out almost free of charge and quickly, even immediately; comfort (companies are making more and more efforts to make its use easy, intuitive); ubiquity (especially in the case of cross-border transfers), etc. Additionally, in the case of China, with a huge population, has better internet connections and new generations of digital natives. Let us also think that we are talking about new forms of money, with a direct impact on the banking sector in some countries, and therefore on consumer protection and financial stability ${ }^{9}$. Aware of the challenge of achieving a balance between financial stability, financial inclusion and the fintech phenomenon, the International Monetary Fund and the World Bank explicitly include, in the so-called "Bali Fintech Agenda", 12 high-level issues for consideration from the authorities ${ }^{10}$.

${ }^{7}$ Partnership for Finance in a Digital Africa, "Focus Note: Can Big Data Shape Financial Services in East Africa?", Farnham, Surrey, United Kingdom, Caribou Digital Publishing (2018): http://www.financedigitalafrica.org/wp-content/uploads/2018/03/FiDA-CanBig-Data-Shape-Financial-Services-in-East-Africa.pdf

${ }^{8}$ Chorzempa, M., "Por qué las 'fintech' triunfan en China pero no en el resto del mundo", MIT Technology Review (2019): https://www technologyreview .es/s/10833/por-quelas-fintech-triunfan-en-china-pero-no-en-el-resto-del-mundo

${ }^{9}$ Hernández de Cos, P., "Central banks, financial inclusion and digitalization: harnessing technology for inclusive growth", Conference "Financial integration and inclusive development: A view from the Mediterranean Countries"/Banco de España e Instituto del Mediterráneo (IEMed) (2019): https://www.bde.es/f/webbde/GAP/Secciones/SalaPrensa/ IntervencionesPublicas/Gobernador/Arc/Fic/hdc131219en2.pdf

10 FMI, "The Bali Fintech Agenda" (2018): https://www.imf.org/en/Publications/PolicyPapers/Issues/2018/10/11/pp101118-bali-fintech-agenda; Barruetabeña, E., "La influencia de las nuevas tecnologías en la inclusión financiera", Boletín económico del Banco de España (artículos analíticos), 1/2020 (2020): https://www.bde.es/bde/es/secciones/informes/boletines/ Boletin_economic/ 
In the European Union (EU), the circumstances in which access to the data kept by the platforms may be essential to guarantee healthy competition is being assessed. In these cases, it might be necessary to establish a clear framework of obligations that enables their open and generalized exchange, overcoming the current scope limitations of the Second Payment Services Directive ${ }^{11}$ (PSD2). The joint appearance, in July 2020, of the CEOs of four of the largest technology companies in the world before the Judicial Committee of the United States Congress, in the framework of an investigation into alleged anti-competitive practices, serves as an exam$p l e^{12}$. It is clear that legislators and policy makers must be prepared for some disruption in the banking landscape ${ }^{13}$. Opacity, unilateral commercial conditions and abusive clauses, justify the proliferation of public actions ${ }^{14}$. Due to its importance, within the EU, the Regulation on the promotion of equity and transparency for professional users of online intermediation stands out ${ }^{15}$.

\section{The development of cryptocurrencies}

In relation to maximizing the use of emerging technologies to change existing models of financial services, deserves especial attention the use of Blockchain (translated as "chain of blocks"), and cryptocurrencies (cryptographic currencies - using mathematics and advanced computer techniques should also be analyzed-, or cryptocurrencies - a new type of asset or virtual currency -) such as "Bitcoin" (BTC). This virtual currency originated in 2009 as a means of payment by Satoshi Nakamoto, and operates with blockchain technology. Bitcoin represents more than $60 \%$ of the total

11 Directive (EU) 2015/2366 of The European Parliament and of The Council of 25 November 2015, on payment services in the internal market, amending Directives 2002/65/EC, 2009/110/EC and 2013/36/EU and Regulation (EU) No 1093/2010, and repealing Directive 2007/64/EC. OJ L 337, 23.12.2015, p. 35-127.

12 Gorjón, S., "Plataformas digitales: avances en su regulación y retos en el ámbito financiero", Boletín económico del Banco de España (artículos analíticos) (2020): https://www. bde.es/bde/es/secciones/informes/boletines/Boletin_economic/

13 Mancini Griffoli, T. y Adrian, T., "The rise of digital money", Fintech Notes: International Monetary Fund (2019): https://www.imf.org/en/Publications/fintech-notes/ Issues/2019/07/12/The-Rise-of-Digital-Money-47097

${ }^{14}$ Gorjón, S., "Plataformas digitales: avances en su regulación y retos en el ámbito financiero", Boletín económico del Banco de España (artículos analíticos) (2020): https://www. bde.es/bde/es/secciones/informes/boletines/Boletin_economic/

15 Regulation (EU) 2019/1150 of The European Parliament and of The Council of 20 June 2019 on promoting fairness and transparency for business users of online intermediation services. OJ L 186, 11.7.2019, p. 57-79. This rule has been applied since July 12, 2020. 
market capitalization in the virtual currency market ${ }^{16}$. But although some cryptocurrencies such as bitcoin have limits on the issuance of their total number, there is no limit on the various cryptocurrency brands that could be issued. Currently, there are more than 2,000 different cryptocurrencies and the proliferation of such currencies is likely to lead to suboptimal or unstable balances and affect price stability ${ }^{17}$.

Unlike conventional convertible currencies, this type of virtual currency is not endorsed or regulated by any issuing entity (for example a government or a central bank), and therefore it is defined as a cryptic, encrypted and anonymous currency. The fact that, since its creation, bitcoin has a limit of 21 million (one of which is in the hands of Nakamoto and out of circulation), makes it a rare asset with great potential for revaluation. That bitcoin, or any other cryptocurrency, lacks an intrinsic value like that of gold and is not backed by a State, such as sovereign currencies, makes its price determined exclusively by supply and demand ${ }^{18}$. The European Central Bank (ECB) does not consider bitcoin a currency, considering that a currency must be a reliable store of value, in the sense that citizens have to be certain that with the money they have today, they will be able to buy roughly the same things tomorrow or a year from now. However, bitcoin is not stable. Its value has skyrocketed and plummeted in the space of a few days. Thus, the ECB considers it a "speculative asset", a bet to obtain a profit, but with the risk of losing the investment. Perhaps that is why a regulation (known as MiCA) is currently being negotiated at the European level that aims to establish a regulatory framework for the issuance of crypto assets and service providers on them (COM/ 2020/593 final $)^{19}$.

${ }^{16}$ Mazanec, J., "Portfolio Optimalization on Digital Currency Market", Journal of Risk and Financial Management 14(4):160 (2021). DOI:10.3390/jrfm14040160: https://www. researchgate.net/publication/350618647_Portfolio_Optimalization_on_Digital_Currency_ Market

17 Saches, D.R., "Bitcoin Vs. The Buck: Is Currency Competition a Good Thing?", $\mathrm{Fe}$ deral Reserve Bank of Philadelphia Economic Insights Q2 13 (2018): https://www.philadelphiafed.org/-/media/frbp/assets/economy/articles/economic-insights/2018/q2/eiq218-bitcoin. pdf

18 Pintado, C., "En 2021 un bitcoin vale 40.000 dólares", The Conversation (2021): https://theconversation.com/en-2021-un-bitcoin-vale-40-000-dolares-152249

19 Proposal for a regulation of the European Parliament and of the Council on Markets in Crypto-assets, and amending Directive (EU) 2019/1937. It has focused on regulating all those crypto assets that are not considered by current regulations as financial assets or as electronic money and, therefore, are already regulated under these regulations. The MiCA Proposal applies to all those who issue or advise on the issuance of crypto assets and who provide crypto asset services in the European Union. For these purposes, the Proposal defines cryptoasset as a "digital representation of value or rights, which can be transferred or stored electronically through distributed ledger technologies or other similar technologies". 
Bitcoin reached a new historical maximum in April 2021 above $\$ 65,0002.5$ times what the National Association of Securities Dealers Automated Quotation (NASDAQ) itself is valued as a platform. Its capitalization in April 2021 is 914,578 million US dollars, a figure almost five times higher than that of the next on the list (of cryptocurrencies), Ethereum, with 206,676 million dollars (CoinMarketCap.). Information that the Statistics Portal for Market Data (Statista), has also published. Following approval by the US Securities and Exchange Commission, the April 2021 IPO of Coinbase (COIN) (the first time a crypto company has done so , the world's leading cryptocurrency seller), shows the rise of digital currencies and forces a rethinking of their role in the future. Precisely, taking advantage of the increase in Bitcoin, active users of Coinbase grew $117 \%$ in the first quarter of 2021 ; revenues exceed $\$ 1.8$ billion $^{20}$. Although expectations were already high, the valuation of this new stock surpassed them, and The New York Times called it a "historic moment" for bitcoin and the entire cryptocurrency industry ${ }^{21}$. According to data from the website (Coin ATM Radar), there are currently around 15,600 cryptocurrency ATMs. Most of them are in the United States, with more than 12,900 . Spain has 102 devices, which places it as the fifth country in the world with the most cryptocurrency ATMs ${ }^{22}$.

Now, the interest in this cryptocurrency and its revaluation comes mainly from institutional investors, mainly investment funds, whose clients are familiar with electronic currencies and find in bitcoin a way to diversify the risk in their portfolios and protect their assets. One of the reasons for this interest is that, with the crisis generated by the pandemic, central banks have intervened in financial markets through the implementation of zero or negative interest rates, the purchase of sovereign debt and the printing of currency. Investors fear that this monetary policy will lead the economies to a scenario of inflation and currency devaluation ${ }^{23}$. It must be taken into account that, since the crisis of 2008, financial markets, with low interest rates, have hardly had assets - neither

${ }^{20}$ Nasdaq, "Riding Bitcoin Surge, Coinbase Active Users Grew by 117\% in Q1 2021; Revenue Tops \$1.8B” (2021): https://www.nasdaq.com/articles/riding-bitcoin-surge-coinbase-active-users-grew-by-117-in-q1-2021-revenue-tops-\%241.8b-2021

21 The New York Times, “Coinbase Valued at \$86 Billion in 'Landmark Moment' for Crypto” (2021): https://www.nytimes.com/live/2021/04/14/business/stock-market-today

22 Mena Roa, M., "España, quinto país del mundo con más cajeros de criptomonedas", Statista (2021): https://es.statista.com/grafico/24241/paises-con-mas-cajeros-automaticos-decriptomonedas-instalados/

23 Pintado, C., "En 2021 un bitcóin vale 40.000 dólares", The Conversation (2021): https://theconversation.com/en-2021-un-bitcoin-vale-40-000-dolares-152249 
fixed income nor variable, neither gold or raw materials - with attractive returns comparable to crypto ${ }^{24}$.

Likewise, as some authors point out ${ }^{25}$, the adoption of this blockchain technology will be slow for various reasons. The first is the slowness of the system itself: the security benefits provided by a decentralized, replicated and distributed registry have as a counterpart its inefficiency when compared to a classic database, not only in processing time, but also in computing resources. Thus, the large amount of energy resources consumed is one of the most important criticisms ${ }^{26}$. In addition, with a new version of the system, it is necessary to migrate all the data to preserve the history, which makes the updates very slow. As a member of the European Court of Auditors points out, all this is made even more difficult by problems related to privacy. Encryption is a solution, but it requires guarantees of preservation. All this without forgetting the questions of legality such as what is the value of smart contracts? Can blockchain traces be used in a court of law? A common regulatory framework is undoubtedly necessary (...) The problem of the legal framework is present in all countries, as well as the

${ }^{24}$ Carbó Valverde, S., "Criptoactivos en Bolsa. La salida a cotización de Coinbase muestra el auge de las monedas digitales y obliga a reconsiderar su papel en el futuro", El País (2021): https://elpais.com/economia/2021-04-15/criptoactivos-en-bolsa.html

${ }^{25}$ Lander, L., Cooper, N., "Promoting public deliberation in low trust environments; Australian use cases", Social Science Research Network (SSRN) (2017), DOI: http://dx.doi. org/10.2139/ssrn.3077474: http://ceur-ws.org/Vol-1897/paper6.pdf

26 According to the University of Cambridge's Bitcoin Electricity Consumption Index, the world's most famous cryptocurrency is estimated to consume approximately 88 terawatt hours of electricity per year. In these, which are carried out through a process known as mining, voluntary Internet users record market movements in a decentralized way thanks to Blockchain technology. It is this process that causes the energy consumption of Bitcoin to be higher than that of many industrialized countries, such as Belgium, with an expenditure of 82 terawatt hours based on 2016 figures: Mena Roa, M., "Bitcoin consume más electricidad que toda Bélgica", Statista (2020): https://es.statista.com/grafico/18630/consumo-de-electricidadanual-de-bitcoin/. In a study in the journal Nature Sustainability, it is stated that the energy cost of generating this type of money through "mining" is equal to or greater than the cost of extracting the equivalent value in various metals: Krausse, M.J., Tolaymat, T., "Quantification of energy and carbon costs for mining cryptocurrencies", Nature Sustainability, vol. 1 November 2018 (2018), DOI: https://doi.org/10.1038/s41893-018-0152-7. The problem is not the same in all countries: for example, mining in China generated four times more carbon dioxide per cryptocurrency in 2018 than mining in Canada, due to differences in electricity production: Martín, B., "El coste oculto de las criptomonedas", en El País, 10/11/2018 (2018): https://elpais.com/elpais/2018/11/08/ciencia/1541673592_243753.html. In Iceland, digital currencies already used more energy than households in 2018: Keflavic, "La fiebre por minar bitcoins conquista Islandia. El consumo masivo de electricidad para fabricar criptomonedas suscita dudas por su efecto medioambiental. En el país nórdico, las divisas digitales usan ya más energía que las familias”, El País, 26/05/2018 (2018): https://elpais.com/economia/2018/05/24/actualidad/1527176354_921493.html 
lack of guarantees of governance of a public infrastructure without central decision-making structures ${ }^{27}$. All these limitations invite caution. And prudence is also the conclusion of the report of the EU Blockchain Observatory Forum ${ }^{28}$.

In Spain there are modifications in its legislation, for example, the Market Law in March 2021 so that our stock regulator, the National Securities Market Commission - CNMV - , can consult and act in relation to cryptoactive companies, providers of regulated investment services and investors to make the circular on advertising crypto assets. However, despite the existence of a panoply of diverse regulatory strategies, the ECB would have very few options to regulate cryptocurrencies due to its limited mandate, scope of competition and tools to achieve its objectives (...). These legal challenges arise from the potential effects of Central Bank Digital Currency $(C B D C)$ that can undermine the mandate of the ECB or its basic and ancillary tasks, including its tasks of contributing to banking and financial stability. Also, constitutional and legal obstacles may eventually require amendments to the TFEU ${ }^{29}$.

\section{The race for digital currency and its challenges}

In June 2019, Facebook announced its own cryptocurrency called "Libra" (with a subsidiary company, Calibra, its virtual wallet) to be used through two social networks: WhatsApp and Messenger. They initially formed the Libra Association, now called the Diem Association. As J.L. Sánchez for ABC, was offered in order that its value remained stable thanks to the support of banks and electronic commerce companies, linking to different international currencies (thus avoiding the large economic fluctuations of other digital currencies such as bitcoin). Initially, it had the backing of companies such as Visa, Mastercard, Vodafone, PayPal, eBay, Spotify, Uber, Lyft, Booking Holdings (owner of Booking.com, Priceline.

${ }^{27}$ Cordero Valdavida, M., Blockchain en el sector público, una perspectiva internacional, Revista Vasca de Gestión de Personas y Organizaciones Públicas, n. ${ }^{\circ} 6$ zk./2019 (2019): https://www.ospi.es/export/sites/ospi/documents/documentos/Tecnologias-habilitantes/ Blockchain_Sector_Publico_IVAP.pdf

${ }^{28}$ EUBlockchain: (The European Union Blockchain Observatory and Forum), Blockchain and the GDPR. European Commission (2018): https://www.eublockchainforum.eu/sites/ default/files/reports/20181016_report_gdpr.pdf

${ }_{29}$ Nabilou, H., "Testing the waters of the Rubicon: the European Central Bank and central bank digital currencies", Journal of Banking Regulation, 21(12) (2020), DOI:10.1057/s41261019-00112-1: https://www.researchgate.net/publication/335290239_Testing_the_waters_of_ the_Rubicon_the_European_Central_Bank_and_central_bank_digital_currencies 
com and Kayak.com) and the Argentine e-commerce firm, Mercado Libre, among other. This initiative would allow the 2.44 billion monthly Facebook users to have access to exchange dollars and other international currencies, and could be used both for transactions between individuals - in the style of Bizum or Twyp - as well as for purchases in establishments ${ }^{30}$. However, at present many of the indicated companies have disengaged from the project, which is now paralyzed and reformulated (it is no longer considered as a cryptocurrency - and actually being a global currency was its great bet, which differentiated it from the rest of the coins-) $)^{31}$.

From the beginning they made it clear that it was not going to be launched until regulators were satisfied ${ }^{32}$. In the US, they asked Facebook to stop the launch of the cryptocurrency ${ }^{33}$, EU antitrust regulators investigated the matter, with France pointing out that it "threatened the

30 Sánchez, J.M., "Facebook anuncia su criptomoneda Libra para usarse en WhatsApp y Messenger", ABC Redes, 20/06/2019 (2019): https://www.abc.es/tecnologia/redes/abci-facebook-prepara-criptomoneda-apoyo-instituciones-bancarias-201906180143_noticia.html

${ }_{31}$ The body now raises different stablecoins with each of them backed by an existing and regulated currency such as the euro, the British pound or the dollar. There will be a unique "currency" within Libra but it will not be a cryptocurrency as such, but a digital system made up of the already existing stable and regulated currencies. For example, when you send a pound you will actually be sending fractions of dollars or euros: Rus, C., "Libra, la criptomoneda respaldada por Facebook, se reestructura por completo y será más similar a PayPal que a Bitcoin", Xataca, 16/04/2020 (2020): https://www.xataka.com/empresas-y-economia/ libra-criptomoneda-respaldada-facebook-se-reestructura-completo-sera-similar-a-paypal-quea-bitcoin

${ }^{32}$ Marcus, D., Hearing before The United States Senate Committee on banking, housing, and urban affairs. Testimony of David Marcus, head of Calibra, Facebook, 16/07/2019 (2019): https://www.banking.senate.gov/imo/media/doc/Marcus\%20Testimony\%207-16-19. pdf

${ }^{33}$ In a letter to Facebook CEO Mark Zuckerberg, Chief Operating Officer Sheryl Sandberg, and Calibra subsidiary head David Marcus, Rep. Maxine Waters, chair of the House Financial Services Committee , calls for the temporary halt of the project while the United States Congress and regulators investigate potential risks: "We are writing to request that Facebook and its partners immediately accept a moratorium on any advancement of Libra, its cryptocurrency proposal, and Calibra, their digital wallet proposal. Apparently, these products could lend themselves to a completely new global financial system, based in Switzerland and destined to rival the monetary policy of the United States and the dollar. This raises serious problems of privacy, commerce, national security and monetary policy not only for the more than 2 billion Facebook users, but also for investors, consumers and the global economy in general" (02/07/2019): https://financialservices.house.gov/news/documentsingle.aspx? DocumentID $=404009$. Likewise, the US Federal Reserve declared that "Libra casts doubt on the financial and banking system worldwide": Castillo, T., "Legisladores estadounidenses piden a Facebook que "cese inmediatamente" el lanzamiento de la criptomoneda Libra", Genbeta (03/07/2019) (2019): https://www.genbeta.com/actualidad/ legisladores-estadounidenses-piden-a-facebook-que-cese-inmediatamente-lanzamientocriptomoneda-libra 
monetary sovereignty" of the EU ${ }^{34}$. As if this were not enough, in October 2019 the platform received severe blows when it lost the support first of PayPal and then of others such as Visa, MasterCard or eBay. Government concerns and the fact that Facebook was behind it (as much as they said they weren't going to intervene) increased privacy concerns ${ }^{35}$.

Meanwhile, China is already testing its own cryptocurrency. As it is the same State that creates it (the PBoC, People's Bank of China), it is its own regulator. Four of its banks have already started testing it on mobile phones in 2020, also the electronic payments giant Ant Financial and the wellknown operator Tencent are involved in this deployment. It is called DC / EP (Digital Currency / Electronic Payment) (DCEP). As Pastor points out, one of the curiosities of this coin is that mobile payments can be made even without connection to data networks. Just using NFC technology ${ }^{36}$. Furthermore, the mobile phone will not have to be linked to a bank account, something essential that will allow even people who do not have access to the banking system to have their DC / EP wallet and access to this digital currency. The preliminary application is available for iOS and Android and allows you to show the initial options that will be available in this system: each user will have a DC / EP wallet on their mobile phone with which they can make payments through QR codes - a system already fully extended in China thanks to WeChat mobile payments-, and it will also allow you to send or receive money and even initiate transactions by putting two mobile phones in contact. It could be a stable currency, based on a blockchain with 1: 1 parity with the yuan and backed by the $\mathrm{PBoC}$, offering the public a confidence that private digital currencies cannot obtain ${ }^{37}$.

${ }^{34}$ Pastor, J., "Libra, la criptodivisa de Facebook, "amenaza la soberanía monetaria" de Europa según Francia”, Xataka, 12/09/2019 (2019): https://www.xataka.com/criptomonedas/ libra-criptodivisa-facebook-amenaza-soberania-monetaria-europa-francia.

35 Rus, C., "Libra, la criptomoneda respaldada por Facebook, se reestructura por completo y será más similar a PayPal que a Bitcoin”, Xataca, 16/04/2020 (2020): https://www. xataka.com/empresas-y-economia/libra-criptomoneda-respaldada-facebook-se-reestructuracompleto-sera-similar-a-paypal-que-a-bitcoin

36 NFC stands for "Near Field Communication" and, as the name suggests, enables short-range communication between compatible devices. Just like Bluetooth and Wi-Fi, and all sort of other wireless signals, NFC works on the principle of sending information over radio waves. Smartphones are the most common form of active NFC device. Public transport card readers and touch payment terminals are also good examples of this technology. NFC is a mainstream wireless technology, thanks to the growth of online payment systems like Samsung Pay and Google Pay.

${ }_{37}$ Pastor, J., "China prepara su criptomoneda digital oficial, llamada DC/EP, y cuatro de sus bancos ya están probándola en móviles”, Xataka (2020): https://www.xataka.com/empresas-y-economia/china-prepara-su-criptomoneda-digital-oficial-llamada-dc-ep-cuatro-sus-bancos-estan-probandola-moviles 
DCEP will be used for purchases in all sectors throughout China. It will likely largely displace cash yuan (CNY) / renminbi (RMB) (RMB is the official currency of China, where it acts as the medium of exchange, and the yuan is the unit of account of the country's economic and financial system ). By mid-2020, DCEP has been piloted in the Chinese cities of Shenzhen, Chengdu, Suzhou and Xiong'an, potentially reaching more than 42 million people, more than the entire population of Canada. Elsewhere in China, DCEP is in the process of being a pilot in the restaurant and hospitality sectors, with foreign multinationals such as McDonald's, Starbucks and Subway. DCEP trials are already underway in China to reimburse travel costs for public sector employees ${ }^{38}$. Surely as "Libra" intended to do, the Chinese authorities will link the DCEP with important companies already known outside the country such as Alipay and WeChat $\mathrm{Pau}$, and will use it for international trade, which can make it an alternative to the traditional international payment system , compared to the current one led by the United States with the USD, and for now the only one with a digital currency, with just a "click" on the mobile phone. The Belt and Road Initiative (BRI) offers, never better said, "the belt and the road" to extend the Yen (through the DCEP) as a medium of exchange in countries around the world, as a global currency. These concerns, for example the change in the position of the dollar at the international level, its challenges, have already had a broad resonance for many months in areas such as the World Economic Forum ${ }^{39}$.

As the Chinese Government itself issues this digital currency, it can impose the most appropriate legal coverage for its purposes (remember, for example, its lax treatment of data protection), and as it is the work of the $\mathrm{PBoC}$, it lacks opponents who claim a monopoly or threat to their sovereignty. The strong economic implication in its implementation is obvious, something not strange in all kinds of experimentation and development in innovation by the "Asian Dragon" that quickly gobbles up any technological opportunity. Its high competitiveness occurs as "The art of bian lian, or" face change "(an integral part of Sichuan opera in which a main character changes his mask to avoid being captured by

38 Prud'homme, D. y Xu, J., "China's digital currency revolution and implications for global business strategy", Preprint, forthcoming in London School of Economics Business Review, August 2020 (2020), DOI: 10.13140/RG.2.2.18819.94240: https://www .researchgate. net/publication/343524884_China's_digital_currency_revolution_and_implications_for_global_business_strategy/link/5f2e87fd92851cd302e7e0b2/download

${ }^{39}$ Guedes P., Gopinath G., Tooze A., Ning Z., Centeno M., "Challenging the Dominance of the Dollar", en World Econocmic Forum (2020): Challenging the Dominance of the Dollar $>$ World Economic Forum Annual Meeting I World Economic Forum (weforum.org) 
enemies $)^{40}$. The transformation is fast and surprising, the new face clearly different. In the business theater, Chinese artists are undergoing a rapid transformation of their own as they seek to evolve from underground producers to the face of world-leading innovation ${ }^{41}$. Will this situation force other countries to launch their own digital currency? Even without certain guarantees, reservations and regulations because of the speed that the response will require?

Japan is also restless about the race towards the DCEP (Chinese digital currency). But will Japan be able to counter the virtual yuan so quickly? The concept of CBDC is not something new, just like that of cryptocurrencies (CBDC) is a form of digital fiat money that is issued by the central bank of a country and as such legal tender value in that nation, that they are not cryptocurrencies or bitcoin). One of the first mentions of a CBDC was made by James Tobin, in his article entitled: "Financial innovation and deregulation in perspective" published by the Institute of Monetary and Economic Studies of the Bank of Japan in $1985^{42}$. Therefore, it was an idea that already existed, but that did not materialize, probably due to the need for control of traditional banking entities, and the inconveniences that they anticipated in the financial system. In February 2019, the Bank of Japan (BOJ) released several reports on CBDCs. For example, a paper written by a BoJ official and a University of Tokyo professor studied different ways to implement a CBDC like the digital yen, and the hypothetical consequences of those approaches ${ }^{43}$, or another more focused on the legal problems that would arise $\mathrm{e}^{44}$.

${ }^{40}$ Chinese Embassy in Spain, "Un artista callejero interpreta Bian Lian, o cambio de rostro, un antiguo arte dramático chino que forma parte de la Ópera de Sichuan" (video posted on the official twitter of the Chinese Embassy in Spain) (2020): https://twitter.com/ chinaembesp/status/1299324569900249088?lang=el

${ }^{41}$ Prud'homme, D. y Von Zedtwitz, M., "The Changing Face of Innovation in China", MIT Sloan Management Review (2018): https://sloanreview.mit.edu/article/the-changingface-of-innovation-in-china/

42 Tobin, J., "Financial Innovation and Deregulation in Perspective", Bank of Japan Monetary and Economic Studies, 3 (1985): https://www.imes.boj.or.jp/research/papers/english/ me3-2-3.pdf

43 Yanagawa, N. y Yamaoka, H., Digital innovation, data revolution and central bank digital currency, Bank of Japan Working Papers Series, n. ${ }^{\circ} 19$ (2019): https://www.boj.or.jp/en/ research/wps_rev/wps_2019/data/wp19e02.pdf

${ }_{44}$ Hayashi, K.; Takano, H.; Chiba, M.; Takamoto, Y., "Summary of the Report of the Study Group on Legal Issues regarding Central Bank Digital Currency", Bank of Japan Research Laboratory Series, n. ${ }^{\circ} 19$ (2019): (Research Lab) Summary of the Report of the Study Group on Legal Issues regarding Central Bank Digital Currency: 日本銀行 Bank of Japan (boj.or.jp) 
In February 2020, Akira Amari, former Minister of Economy and member of the ruling Liberal Democratic Party, led a group of lawmakers who called on his government to push for the inclusion of digital currencies on the G-7 agenda to be held from 10-12 June at Camp David (Washington) as was done, although it was already a concern that had been discussed in different international forums. The case of Japan is especially particular, because it is a country that relies heavily on physical money and hardly makes electronic payments. The Japanese Prime Minister declared that by $2025,40 \%$ of payments would be made without cash, and the best method for Japan to carry out this transformation according to some authors, is through Bitcoin technology ${ }^{45}$.

The BOJ still has no imminent plans to issue digital currency; it is the same as other countries such as the United States, which continues to evaluate the potential implications (security, monetary policy, etc.), giving a wide margin of opportunity for China. In addition, in the case of Japan, it would imply changing the culture of the cash-loving country, since only in recent years, and due to the Olympic Games, a strong advertising campaign is being carried out so that citizens simply buy through a credit card. Furthermore, the Central Bank of South Korea published in February 2021 a book on the legal issues that would need to be addressed to ensure the smooth operation and usefulness of a future central bank digital currency. The digital currency would be based on blockchain technology and allow people to send money directly to each other without the need to go through a bank or other intermediary, thus reducing transaction cost ${ }^{46}$. Also, on January 22, 2020, the Hong Kong Monetary Authority (HKMA) and the Bank of Thailand (BOT) officially announced the results of a joint CBDC research project, called the Inthanon-LionRock Project. Moreover, to publishing a joint press release ${ }^{47}$, banks have released a detailed 90-page report ${ }^{48}$, providing a comprehensive analysis of the potential risks and

45 Orcutt, M., "La apuesta de sustituir el efectivo por b lockchain se decide en Japón", MIT Technology Review (2019): https://www.technologyreview. es/s/10900/la-apuesta-desustituir-el-efectivo-porblockchain-se-decide-en-japon

${ }^{46}$ Huillet, M., "El Banco de Corea publica un libro sobre las cuestiones jurídicas de su moneda digital del banco central", Cointelegraph (2021): https://es.cointelegraph.com/news/ bank-of-korea-publishes-book-on-central-bank-digital-currency-s-legal-issues

47 Bank of Tailand, "Joint press release The Outcomes and Findings of Project Inthanon-LionRock and the Next Steps (BOT and HKMA)": https://www.bot.or.th/English/FinancialMarkets/ProjectInthanon/Pages/Inthanon_LionRock.aspx

48 Bank of Thailand and Hong Kong Monetary Authority, "Inthanon-LionRock Leveraging Distributed Ledger Technology to Increase Efficiency in Cross-Border Payments" (2020): https://www .bot.or.th/English/FinancialMarkets/ProjectInthanon/Documents/InthanonLionRock.pdf 
benefits of CBDCs for real-time money transfers, liquidity management, regulatory compliance, and other aspects of finance ${ }^{49}$.

The race for digital currency has been unleashed. Many central banks around the world prepare their digital currencies, given the growth of cryptocurrencies, technological developments, online purchases with the growing use of electronic banking to make payments (specially in retail payments - the pandemic has accelerated this trend and has even incorporated new users $)^{50}$, and the fear of the systemic risk of a private digital currency in the hands of billions of users, also anticipating other similar currencies and therefore in support of European sovereignty and the security of citizens (in response to unsupervised private solutions). The $\mathrm{CBD}$ is a central bank digital currency. The launch of the central bank digital currency (CBDC) will change the model of commercial banking. In the EU, the European banking regulator has not made a formal decision to launch its currency in digital format. The ECOFIN Council of Economy and Finance Ministers is pushing to accelerate such a launch. Thus, it will be under the control of the Eurosystem, with little risk in addition to being accessible in a harmonized manner through supervised entities, convertible at par. This may promote the international role of the euro, and be used, with the necessary changes, as a monetary policy tool. New challenges also arise furthermore to offering this service: harmonizing accessibility criteria and developing its regulation; increase security in procedures ensuring the protection of user data; creating entities for supervision, control, and, where appropriate, sanction. In other words, design it carefully. Possible design features were reviewed in the Eurosystem report ${ }^{51}$.

According to one of the members of the executive committee of the $\mathrm{ECB}$, if it is not properly designed, its main strengths - security and liquidity - could affect monetary and financial stability on three fronts: first, financial intermediation and allocation of capital in normal time; second, financial stability in times of crisis; and third, the operation of the international financial system. It is also worrying when it points out that beyond these design adaptations, economic thinking about the possible impact of a digital euro on financial intermediation is not clear (...) and

49 Partz, H., "Proyecto piloto de Hong Kong y Tailandia basado en DLT para pagos transfronterizos", Cointelegraph (2020): https://es.cointelegraph.com/news/hong-kong-andthailand-pilot-dlt-based-project-for-cross-border-payments

50 European Central Bank, "Study on the payment attitudes of consumers in the euro area (SPACE)" (2020a): https://www.ecb.europa.eu/pub/pdf/other/ecb. spacereport202012 bb2038bbb6.en.pdf?05ce2c97d994fbcf1c93213ca04347dd

51 ECB (European Central Bank), "Report on a digital euro" (2020b): Report on a digital euro (europa.eu) 
that the risks for financial intermediation of issuing a digital euro are potentially more pronounced in times of crisis ${ }^{52}$. In fact, if not designed correctly, in times of crisis a digital euro could accelerate the "digital runs" of commercial banks towards the central bank. This risk could even be selffulfilling, leading savers to reduce their bank deposits and amplifying volatility also in normal times ${ }^{53}$.

In the 2019 ECB report on the European banking liquidity stress test, of the more than 9,000 existing banks in Europe, only 103 were able to face the stress test. In the extreme scenario, a loss in the value of its clients' deposits equivalent to $27 \%$ of the bank's funds is contemplated. In this scenario, only 26 of the 103 European banks suggested that they could hold out for just over 6 months. The crypto world supposes a breach of the financial system. A way by which money leaves the circuit of banks to land in currencies such as bitcoin, or another similar that becomes operational. As Alberto García-Lluis points out, this flight of money and its conversion into crypto, poses a direct threat to commercial banking. Fiat money is worth less and less due to the monetary policies of the ECB and the Federal Reserve Board (FED). The financial system is sustained on the confidence of the society, and a loss of between $5.1 \%$ and $15 \%$ of the deposits of the clients of the banks would weaken the financial sector, and would raise the systemic risk to very dangerous levels. For this author, the alternative is to reduce the risks of convertibility of the financial system, eliminating paper money and forcing commercial banks to transform their business model, freeing up custody of their clients' deposits. This would reduce the systemic liquidity risks, and it frees the bank from a very important part of the abusive costs of its regulation and compliance ${ }^{54}$.

\section{Other conclusions}

These and other concerns have generated intense debates in various areas, such as the G7, World Economic Forum, EU Parliament, BOJ, Hong Kong Monetary Authority, Bank of Thailand - among others -, in relation

52 Panetta, F., "Evolution or revolution? The impact of a digital euro on the financial system, Bruegel online seminar", EBC (2021): Evolution or revolution? The impact of a digital euro on the financial system (europa.eu)

${ }^{53}$ Kumhof, M. y Noone, C., "Central bank digital currencies - design principles and balance sheet implications", Staff Working Papers, No 725 (2018) Bank of England: Central bank digital currencies - design principles and balance sheet implications.

${ }^{54}$ García-Lluis Valencia, A., ¿Acelerará el BCE el lanzamiento de su euro digital?, Blockchaineconomia.es (2021): ¿Acelerará el BCE el lanzamiento de su euro digital? (blockchaineconomia.es). 
to changes in the position of the dollar at the international level; the potential implications in aspects of monetary policy, security, liquidity management; even about China's leadership also at the political level. Let us remember that a large part of the external debt of some countries is in the hands of China, apart from its relevant investments, especially in the East and the Mediterranean in a strategy that seems to want to Balkanize Europe, with a clear geostrategic component. The EU, the US or other countries such as Japan, Korea, etc., are already making attempts to counteract the virtual yuan.

Both the ECB and numerous authors point out that to preserve stability, the digital euro should be designed in a way that prevents it from being used as a form of investment. Panetta and Bindseil point to several possibilities to avoid it such as the idea of limiting the amount of digital euros that individual users can own. This would avoid large inflows of bank deposits, as well as volatile portfolio inflows from abroad, to the central bank. One way to do this, while allowing the use of the digital euro for important transactions, would be to require that incoming funds that exceed a user's limit be redirected to a bank account. The link between private money and digital euro accounts would avoid fragmentation of the user's liquidity and would also be useful for payments made. Large outbound transactions could be made by transferring a combination of digital euro and private money.

Thus, the digital euro launched by the ECB will be a liability of the central bank, while Fiat money is a liability of commercial banks. That will be the biggest change. When the digital euro goes directly from the issuer to the citizen, commercial banks will lose their savings capture, and will have to look for other sources of financing. There are formulas to stop such a drastic change. The commercial bank can be the official distributor of wallets prepared to receive the European currency. Limits can be placed on the holding of digital euros, the type of payments with this currency or the volume of payments. They are formulas shuffled by the ECB to lengthen the transition, while commercial banking prepares. Another option would be to establish a penalizing remuneration for individual users' holdings of digital euros above a certain threshold ${ }^{55}$. In this way, the digital euro could alleviate a very abrupt change and not being a speculative currency, as it has the backing of the EBC (the digital currency will be an electronic form of money - mainly used as a means of payment - issued by the Eurosystem ECB and national central banks), will guarantee the value of

55 Panetta, F. y Bindseil, U., Central bank digital currency remuneration in a world with low or negative nominal interest rates, VoxEU (2020): Central bank digital currency remuneration in a world with low or negative nominal interest rates 
money, even if it is digital, and will be able to maintain the stability of the euro; a "simple, universally accepted, reliable and risk-free means of payment".

China was the first country to introduce fiat money and the concept of legal tender before fiat money. The history of paper money dates back to more than 2000 years ago in China, where bills of exchange (used as money) were known as "flying money." We are currently living a new paradigm in the economy, where knowledge is decentralized to areas that do not come from the financial tradition, and where the use of technology intensifies, for which it is necessary to have technical knowledge and computer tools for which not all they have the same ease of access, displacing traditional intermediaries, reducing competition in financial markets and limiting consumer options. Electronic money, mobile payments and, more recently, cryptocurrencies herald transformative changes in the financial and monetary systems. Will technology companies be able to impose their objectives, even above the interests and decisions of important States? Will this make us dependent? Likewise, China once again bursts onto the international scene with tests of its new virtual currency that can distort the financial system of many countries, threatening even more the international order. Will the European Union and the US succeed in subverting these inconveniences? Will they do it with their own virtual currencies?

There is a confrontation between blocks, where, once again, geopolitics prevails, and where international concertation is essential. Above all, considering that a flawed implementation can have a negative impact not only domestically, but also globally. Entities such as the ECB should: 1) monitor market developments; 2) act preventively in the face of problems foreseen in the financial scenarios identified in the nearest future (for example, by carrying out tests such as "Smart Money" focused on the experimentation of technical aspects and to analyze the different design options of the digital euro); 3) solve the problems arising from new events (for example, preventing the digital euro from causing deposits to shift away from commercial banks); 4) encourage public-private cooperation in the design of digital currencies; that brings stability to the system and, at the same time, allows private actors to develop business models in a competitive space (this would partly mitigate the risks related to the emergence of new privately owned digital currencies).

On the battlefield of global digital competition, countries and principal axis (US-EU-Asia Pacific), seek the advantage of being pioneers in setting standards and fostering a development model. However, even when China intends to increase the yuan's position as an international currency, it may also pose not only a danger, but a greater challenge to raise the internatio- 
nalization of the euro. Some of the most important entities, such as those mentioned throughout this paper, should reach proposals or agreements between the EU, the US and Asia Pacific, which would allow to coordinate a harmonized global response to digital currencies. Multi-CBDC agreements would have the potential to improve efficiency, for example, by reducing the costs of cross-border transactions. Many evidences, reflections, concerns and even answers have been shown in this paper, although, without doubt, the most certain answer to these questions is that the monetary policy and the international financial system will take a vertiginous turn in just a few months.

\section{Sobre la autora}

Rosa María Ricoy Casas es Profesora Contratada Doctora en Ciencia Política en la Universidad de Vigo (Uvigo) y Profesora Tutora con Venia Docendi en la UNED de Lugo. Doctora en Derecho e Historia (Uvigo) y Licenciada en Ciencias Políticas (UNED). Ha sido Vicedecana de Asuntos económicos e Infraestructuras y Coordinadora-Directora del Grado en Dirección y Gestión Pública de 2015 a 2018, y Secretaria del Tribunal de Garantías (Uvigo) de 2011 a 2014. Ha impartido docencia y conferencias en diversas Universidades y Entidades públicas (INAP, EGAP, FEGAMP, Sorbonne, King's College, Corvinus Budapest, Kielce Polonia, Firenze, Sao Paulo, Mar del Plata, etc) y en Congresos destacados en Ciencia Política (IPSA, AECPA, APCP, CEISAL, GIGAPP, REPS, etc). Ha recibido varios premios de entidades como el Consejo de la Abogacía Gallega, la Fundación Alternativas, la USC, o la Asociación Española de Ciencia Política. En la actualidad es Secretaria del Doctorado en Creatividad e Innovación Social y Sostenible (CREA) y Coordinadora del Grupo de Innovación docente "ODS Cities and Citizenship", e imparte varias asignaturas de Grado, Máster y Doctorado relacionadas con la Ciencia Política, las Relaciones Inernacionales, la Filosofía y Teoría del Derecho, el Derecho urbanístico, y el Patrimonio Cultural Subacuático.

\section{About the author}

Rosa María Ricoy Casas is a Lecturer of Political Science at the University of Vigo (Uvigo) and Teacher with Venia Docendi at the UNED of Lugo. PhD in Law and History from the Uvigo and Degree in Political Science. She was Vice-Dean of Economic Affairs and Infrastructures and Coordinator-Director of the Degree in Public Management and Ad- 
ministration from 2015 to 2018, and Secretary of the Court of Guarantees (Uvigo) from 2011 to 2014. He has taught and lectured at various Universities and Public Entities (INAP, EGAP, FEGAMP, Sorbonne, King's College, Corvinus Budapest, Kielce Poland, Firenze, Sao Paulo, Mar del Plata, etc.) and at outstanding Congresses in Political Science (IPSA, AECPA, APCP, CEISAL, GIGAPP, REPS, etc.). He has received several awards from entities such as the Galician Bar Council, the Alternativas Foundation, USC, or the Spanish Association of Political Science. She is currently Secretary of the Doctorate in Creativity and Social and Sustainable Innovation (CREA) and Coordinator of the Teaching Innovation Group "ODS Cities and Citizenship", and teaches several subjects of Degree, Master and Doctorate related to Political Science, International Relations, Philosophy and Theory of Law, Urban Law, and Underwater Cultural Heritage. 


\section{Derechos de autor}

Los derechos de autor (para la distribución, comunicación pública, reproducción e inclusión en bases de datos de indexación y repositorios institucionales) de esta publicación (Cuadernos Europeos de Deusto, CED) pertenecen a la editorial Universidad de Deusto. El acceso al contenido digital de cualquier número de Cuadernos Europeos de Deusto es gratuito inmediatamente después de su publicación. Los trabajos podrán leerse, descargarse, copiar y difundir en cualquier medio sin fines comerciales y según lo previsto por la ley; sin la previa autorización de la Editorial (Universidad de Deusto) o el autor. Así mismo, los trabajos editados en CED pueden ser publicados con posterioridad en otros medios o revistas, siempre que el autor indique con claridad y en la primera nota a pie de página que el trabajo se publicó por primera vez en CED, con indicación del número, año, páginas y DOI (si procede). Cualquier otro uso de su contenido en cualquier medio o formato, ahora conocido o desarrollado en el futuro, requiere el permiso previo por escrito del titular de los derechos de autor.

\section{Copyright}

Copyright (for distribution, public communication, reproduction and inclusion in indexation databases and institutional repositories) of this publication (Cuadernos Europeos de Deusto, CED) belongs to the publisher University of Deusto. Access to the digital content of any Issue of Cuadernos Europeos de Deusto is free upon its publication. The content can be read, downloaded, copied, and distributed freely in any medium only for non-commercial purposes and in accordance with any applicable copyright legislation, without prior permission from the copyright holder (University of Deusto) or the author. Thus, the content of CED can be subsequently published in other media or journals, as long as the author clearly indicates in the first footnote that the work was published in CED for the first time, indicating the Issue number, year, pages, and DOI (if applicable). Any other use of its content in any medium or format, now known or developed in the future, requires prior written permission of the copyright holder. 